\title{
Tánczos Péter
}

\section{Filozófiai szubverzió és politikai kockázat - A demisztifikáció és a felforgató gondolkodás szerepe Nietzsche „machiavelliánus" Spinoza-képében}

\author{
Tánczos, Péter: Philosophical Subversion and Political Risk - The Role of the Demystification and \\ Subversive Thought in Nietzsche's "Machiavellian" Spinoza-interpretation
}

In my paper I attempt to introduce the main points of Nietzsche's inconstant Spinozainterpretations. According to my conception Nietzsche in his affirmative period regarded Spinoza as a subversive thinker who was committed to demystification. I analyse the rotational acts used by the two philosophers and show the limits of this subversive activity. I demonstrate the political aspects of the subversion and try to detect the influence of Machiavelli's "virtù"conception in Nietzsche's affirmative interpretation.

Keywords: Nietzsche, Spinoza, subversion, demystification, Machiavelli

Összefoglaló

A tanulmányomban kísérletet teszek Nietzsche folyton változó Spinoza-értelmezéseinek rövid bemutatására. Nietzsche affirmatív viszonyulása idején Spinozában egy szubverzív, a demisztifikáció iránt elkötelezett gondolkodót vélt felfedezni. Elemzésem során a két szerző rotációs aktusainak múködésmódját és határait vázolom fel. A felforgató aktivitás politikaelméleti aspektusainak ismertetése után igyekszem kimutatni Nietzsche elfogadó magatartásának gyökerében Machiavelli „virtù”- koncepciójának hatását.

Kulcsszavak: Nietzsche, Spinoza, szubverzió, demisztifikáció, Machiavelli

\section{HALOTT-IDÉZÉS NIETZSCHÉVEL}

„Én is jártam az alvilágban, mint Odüsszeusz, és többször is alászállok; ám én nemcsak bárányt áldoztam, hogy beszélhessek néhány holttal, nem kíméltem saját véremet sem" [Nietzsche 2012: 128]. Friedrich Nietzsche az Emberi, nagyon is emberi második kötetének idézett helyén négy emberpárt sorol fel, aki nem zár- kózott el előle alvilágaárása során: Epikuroszt és Montaigne-t, Goethét és Spinozát, Platónt és Rousseau-t illetve Pascal és Schopenhauer kettősét. A felsorolt szerzőkben nem Nietzsche habituális, stilisztikai vagy doxografikus előképeit kell keresnünk, hanem sokkal inkább olyan potenciális vitapartnereket, akik valamiféle kihívással szolgáltak a könyvek halott világába merészkedő gondolkodó számára. A filozófusok eredendő anakronizmusának gondolata köszön vissza ezekből a sorokból [Nietzsche 2001b: 5]: saját korának előítéleteit úgy tudja meghaladni magában, ha eleven eszmecserét folytat a rég halott gondolkodókkal. Paradox módon az elevenség lehetőségét éppen a fenti metaforikus alvilágjárás nyitja meg: ez a nyolc nagy elme halott voltában olyan élőnek és életre szomjazónak hat, amely ellentétbe állítható az „örök élet" után sóvárgó hétköznapi, valóban élő emberekkel [Nietzsche 2012: 408].

Az idézett aforizma nem csak a lehetséges beszélgetőpartnerek személyét rögzíti, hanem hozzávetőlegesen körvonalazza a korokon átívelő dialógus metódusát és paramétereit is:

„Velük kell mindent megvitatnom, miután oly sokáig bolyongtam egyedül, mondják meg 
ők, igazam van-e vagy sem, őket akarom hallani, miközben egymásnak is igazat adnak vagy sem. Bármit mondok is, bármilyen döntésre jutok is, bármit gondolok is ki magamnak és másoknak: e nyolc alakra szegezem tekintetem, és látom, hogy ők is rám tekintenek" [Nietzsche 2012: 128].

Ez a figyelem tehát korántsem egyoldalú, hanem valódi eszmecsere: a múlt nagy szerzői is tekintettel vannak Nietzschére. Az első olvasásra abszurdnak tűnő hatástörténeti összefüggés jelentősége és jelentése rögtön érthetővé válik, ha egy különös interpretációs technika kontúrjait keressük a szövegben. Ha így közelítünk a meglepő kijelentéshez, akkor eltűnik annak provokatív éle: a mindenkori olvasót reprezentáló Nietzsche rendelkezik egy olyan sajátos hermeneutikai diszpozícióval, amely lehetetlenné teszi, hogy teljesen függetlenítse magát az elemzett korpusz általa ismert utóéletétől, hatástörténeti összefüggéseitől. Amennyiben tehát Spinozát megszólítjuk, értelmezve olvassuk, (a nietzschei intenciók értelmében) Spinoza szükségszerűen válaszolni fog. Természetesen fontos leszögezni, hogy a megidézett Másik nem az egykor élt gondolkodó lesz, hanem az ő eleven árnya, jelen esetben a Nietzsche által életre hívott Spinoza.

\section{NIETZSCHE AMBIVALENS SPINOZA-KÉPE}

Bár Nietzsche a felsorolt nyolc szerző mindegyikével meglehetősen ambivalens viszonyban állt, a Spinozával való értelmezői kapcsolata különösen összetett volt. Minden érték átértékelője egymásnak teljességgel ellentmondó nyilatkozatokat hagyott ránk filozófus-elődjéről: a féltékenységgel határos csodálattól az érdektelen közönyön át a totális elutasításig terjedt kognitív és affektív megnyilvánulásainak skálája. Bár az egy időben keletkezett kijelentések terén is tapasztalhatunk némi hezitálást, megítélésbeli differenciát, ha alaposabban szemügyre vesszük a ránk maradt Spinoza-utalásokat, könnyen felfedezhetünk Nietzsche életművében egy történeti interpretációs ívet.
Korai feljegyzéseiben Nietzsche nem mutatott különösebb érdeklődést Spinoza iránt: a gondolkodó neve ezeken a szöveghelyeken többnyire csak mint egy fenntartásokkal kezelt filozófusi-szerzői típus szimbóluma, mint egy köznevesített jelző vagy metonimikus elem szerepel [KSA 7: 434; KGB II/5: 291, 468]..$^{1}$ Ennek ellenére találhatunk egy-két olyan passzust is, ahol Nietzsche más múvek elemzése során feljegyzi Spinoza valamely releváns gondolatát [KSA 8: 133], még ha azok interpretálásába nem is megy bele. Sőt, a bázeli klasszika-filológiai professzori állását frissen feladó Nietzsche egyik jegyzetfüzetében latin eredetiben idézi Spinoza egy számára szimpatikus megállapítását, amely magyarul így hangzik [KSA 8: 346]: „A szabad ember semmire sem gondol kevésbé, mint a halálra; bölcsessége nem a halálról, hanem az életről való elmélkedés" [Spinoza 1969: 261]. Az Emberi, nagyon is emberi címú könyvében Spinoza már az okos, tudós géniusz ideáltípusaként és a zsidó nép egyik legnagyobb ajándékaként, a „legtisztább bölcsként” jelenik meg [Nietzsche 2008: 93, 190].

A Spinozával szembeni távolságtartó tisztelet hangja A vidám tudomány írása közben tűnik el [Wollenberg 2013: 617], hogy helyét először átvegye a fokozott érdeklődés, majd a féltékenységgel vegyes csodálat érzése. Egy 1881. július eleji levelezőlapján Nietzsche jelzi Franz Overbeck-nek, hogy szüksége lenne pár könyvre a nyári szabadsága idején [KGB III/1: 100-101]. A felsorolt könyvek között ott van Kuno Fischer Spinozáról szóló kötete is, amelyről a hónap végén már a legnagyobb lelkesültség hangján ír szintén Overbeck-nek [KGB III/1: 111]. Nietzsche Spinozában saját gondolkodói elődjét fedezi fel: „Egészen megdöbbentem, egészen el vagyok ragadtatva! Van egy előfutárom, méghozzá micsoda előfutárom!" [KGB III/1: 111] Öt alapvető elutasító gesztusban találja meg a kettejük közötti

${ }^{1}$ A továbbiakban a magyarul nem hozzáférhető Nietzsche munkák esetében a Kritische Studienausgabe (KSA), a levelek esetében pedig a Kritische Gesamtausgabe Briefwechsel (KGB) megfelelő kötet- és oldalszámait adom meg. 
hasonlóságot: az akaratszabadság, a teleológia, a morális világrend, az „un-egoizmus” és a gonoszság tagadásában. Odáig megy, hogy a kettejük közötti eltéréseket javarészt az időben, a kultúrában és a tudományban azóta bekövetkező változásoknak tulajdonítja. Az addig tapasztalt hegyvidéki magányossága egy „magaslati” társas viszonnyá alakult át (Nietzsche szavaival: az „Einsamkeit” állapotából „Zweisamkeit” lett). Ennek ellenére Nietzsche meglepődve tapasztalja, hogy nem elégedett annyira a helyzetével, mint remélte - bár a szövegkörnyezet megengedi azt is, hogy ez a várakozásával kapcsolatos hiányérzet már nem a Spinoza-élmény okozta szellemi légkörre, hanem az egészen konkrétan értett időjárásra vonatkozik [KGB III/1: 111].

A csodálat időszaka nem tartott tovább pár hónapnál: bár még évek múlva is előfordult, hogy hízelgően nyilatkozott Spinozáról (például a hozzá címzett, hagyatékban maradt versben - vö. KSA 11: 319), a hirtelen, exponenciálisan szaporodó Spinoza-feljegyzések elmélyítették a már jelzett hiányérzetet, és nyilvánvalóvá tették Nietzsche számára, hogy a különbségek nem csupán a történelmi változásoknak tudhatóak be. Szemléletes példával szolgál ebben a tekintetben az éppen akkoriban készülő $A$ vidám tudomány című munka: míg a mű első három könyvében az alapvetően eddig megszokott, majdhogynem semleges Spinoza-emlegetéseket találjuk, addig az utolsó két könyvben már a gondolkodó-előd explicit elutasításával találkozhatunk - éppen csak a két állapot között keletkező, rajongó hangvételű aforizmák nem kerültek be a kötetbe. A könyv vége felé található, 333. aforizmában Spinozával szemben pont a megismerés és az intellektus magánvalóságát, önálló származását tagadja: szerinte éppen hogy az intelligibilisről Spinoza által leválasztott, attól elkülönített nevetés, gyász és megvetés (Nietzsche által ösztönnek nevezett) minőségeiből, pontosabban azok harcából keletkezett a megismerés [Nietzsche 2003a: 183]. Máshol pedig felrója a „tüdőbajos Spinozának", hogy a hatalom törekvő kiterjesztése helyett az önfenntartási ösztönben látta az eredendő késztetést: ínséges körülményei proto-Darwinná tették őt [Nietzsche 2003a: 207]. Miután ezekben a Nietzsche szemében sarkalatos kérdésekben az elfogadhatatlan álláspontot képviselte, a nem olyan rég még eleven szellemként megidézett Spinoza már sápadt, vérszívó kísértet lett:

„[...] a régi filozófusok szívtelenek voltak: a filozofálás mindig egyfajta vampirizmus volt. Olyan alakokban, mint például Spinoza, nem éreztek valami mélységes rejtélyt és félelmetes titokzatosságot? Nem látjátok, miféle színjáték játszódik le itt, nincs szemetek az egyre sápadtabbá válásra, a mindegyre idealistább módon értelmezett elérzéktelenítésre? Nem gyanítjátok a háttérben régóta rejtező vérszívót, aki az érzékekkel kezdi és a csontokat, a csontzörgést hagyja utoljára? - mármint a kategóriákat, képleteket, szavakat (mert, már bocsáttassék meg nekem, de ami Spinozából megmaradt, az amor intellectuadis Dei [...], az csak afféle csontzene, nem egyéb, ugyan mi az amor, mi a deus, ha minden csepp vér hiányzik belőlük?...)" [Nietzsche 2003a: 243244]

Spinoza kiemelt, vitapartneri státusza ezzel zárójeleződött: éppen, hogy elevensége, a rokonság atavisztikusan² feltörő képzete (mint kritérium) veszett el. Nem lényegtelen körülmény, hogy Nietzsche az amor intellectus Dei spinozai kategóriáját említi, mint utolsó érték-maradványt, a vérszívás hátrahagyott emészthetetlen maradékát. Az Isten halálát

\footnotetext{
$2 \mathrm{Az}$ atavizmus az anakronizmushoz hasonlóan fontos elvárás Nietzschénél. Vö.: „És mint lengyelben is szörnyű atavizmus testesül meg bennem. Évszázadokra kellene visszanyúlni, hogy rátaláljunk erre a földön létező legnemesebb fajtára, amelynek ösztönei olyan tiszták, mint az enyémek." [Nietzsche 2003b:19]
} 
hirdető Nietzsche eredetileg éppen az „Isten iránt való értelmi szeretet" ismereti nemét [Spinoza 1969: 306] találja igazán produktív erejü gondolatnak, amelyben saját amor fati elnevezésű koncepciójának előzményét véli megtalálni [Sommer 2012: 156. skk.; Volker 1996: 191]. Az amor fati gondolatát, amelyet saját „legbensőbb természetének” nevez [Nietzsche 2003b: 122], Nietzsche az Ecce Homo-ban így mutatja be: „Az emberi nagyság az én nyelvezetemben amor fati: az ember ne akarjon mást, se előre, se hátra, soha. A szükségszerűt nem elegendő elviselni, még kevésbé szabad eltitkolni - mindenféle idealizmus a szükségszerű meghazudtolása -, a szükségszerüt szeretni kell..." [Nietzsche 2003b: 51]. Joggal merül fel a kérdés, hogy mi köze van ennek az Ugyanannak örök visszatérésének affirmatív aspektusával rokonítható gondolatnak [Yovel 1989: 126] Spinoza értelmi szeretetéhez? Nietzsche több ízben hivatkozik szövegeiben Spinoza Deus sive natura tételére, ám egy helyen megfordítja az azonosítás irányát: „natura sive deus” [KSA 11: 557]. Feltételezi, hogy Spinoza ezt a kommutatív jelleget beleértette Isten és természet azonosításába, ezáltal a szükségszerűség két formája (isteni és természeti) iránti szeretet lényegében ugyanarra az igenlő attitűdre vezethető vissza. Nietzsche hamar feladta ezt az elképzelését: nem sokkal később már mint egy magasrendű rettegési formát interpretálja az isteni szeretet [Nietzsche 2001a: 200].

Most, hogy hozzávetőlegesen körvonalaztuk a rövid idő alatt lezajlott, kettős interpretációs váltás körülményeit, időzzünk el rövid időre azon a ponton, amikor Nietzsche éppen lelkesedett Spinozáért, amikor elődjére ismerte benne! Igen valószínűnek tűnik, hogy a szellemi rokonság érzése nem csupán néhány konceptuális analógiából fakadt, hanem valami eredendő szemléletbeli azonosság képzete táplálta azt.

\section{A DEMISZTIFIKÁCIÓS PROGRAM}

A már idézett, rajongó levelében Nietzsche öt közkeletű „,tévedés” tagadása miatt érez rokonszenvet Spinozával: ez a vélt közösség képezi entuziazmusa alapját [KGB III/1: 111]. Egyáltalán nem tekinthető véletlennek, hogy éppen az elvetés, elutasítás aktusában látja meg a szellemi szimpátia okát: Nietzsche úgy ítéli meg, hogy Spinoza éppen olyan magaslati levegőt szív, mint ő; éppen úgy a filozófiai középszer hirdetői felett áll. Mindketten elutasítják a széles körben vallott, konszenzuális jellegük miatt elfogadott nézeteket, mint például az önzetlenség eszméjét vagy a moralitás feltétlen dominanciáját. Nietzsche Spinozában harcostársra bukkan, egy olyan elődre, aki hozzá hasonlóan küzdött kora babonaságaival, aki szintén szubverziós igénynyel lépett fel a filozófia színpadára.

A Bálványok alkonyában a kalapáccsal való filozofálás ideálját [Nietzsche 2004: 7] propagáló Nietzschében gyakorlatilag bölcseleti munkássága első pillanatától jelen volt a felforgató, a közkeletű nézeteket kikezdő attitűd. Gilles Deleuze fel is hívja rá a figyelmet, hogy Nietzsche számára a filozófia mindenekelőtt az alantas gondolkodás leleplezésére szolgál [Deleuze 1999: 167]. Elemzésében elsősorban A vidám tudomány 328. aforizmájára támaszkodik, amelyben Nietzsche a filozófia legfőbb törekvését egy különös imperatívuszban látja meg: kárt kell okozni a butaságnak [Nietzsche 2003a: 180]. Fontos kihangsúlyozni, hogy itt nem az ostobaság kiirtásáról, a tévedések felszámolásáról van szó, hanem a cél maga a permanens károkozás: rossz lelkiismeretet kell kelteni a butaságban. Ez nem egyenlő a szokványos felvilágosító törekvéssel, a népmúvelő szándék egyik alakváltozatával, hanem ez nem más, mint az egyre ellaposodó, önhitegető, kényelmes magyarázatokat kiötlő és alapvetően erodálódó gondolkodással szembeni rotációs gesztus. A butaság masszívan jelenlévő minő- 
ségét nem lehet eltüntetni, mivel butának lenni túlzottan is kényelmes és gyakran célravezető: a nietzschei filozófus vállalja törekvése hiábavalóságát, és portyázó, fosztogató műveletekbe kezd az alantas gondolkodással szemben. A valódi gondolkodás soha meg nem nyugvó természetét szubverzív aktusokkal tartja ébren: az „akol-meleg” közvélekedés kényelmes státuszát igyekszik tönkretenni, állandó felforgatással ellehetetleníteni.

Nietzsche tehát nem véletlenül emeli ki Spinoza kapcsán a tagadások jelentőségét: úgy hiszi, elődjét az övéhez hasonló szándékok mozgatták, hogy Spinoza munkásságában szintén ezeket a szubverzív mozgásokat lehet tetten érni. A mind Nietzsche, mind Spinoza munkásságát affirmatíve interpretáló Deleuze hasonlóképpen látja ezt: Spinoza esetében is kiemeli a hétköznapi vélekedéssel szembeni harc jelentőségét. A filozófia alapvető gyakorlati feladata, hogy leleplezze a babonaságot, a mítoszokat [Deleuze 2000: 324]. Ez a demisztifikációs program bizonyos pontokon rokonítható Nietzsche törekvésével, erre utal az is, hogy Deleuze Spinoza praktikus filozófiájával foglalkozó könyvét éppen Nietzsche egy megjegyzésének felidézésével kezdi [Deleuze 2001: 3].

A demisztifikáció kapcsán mindenképpen fontos kiemelni, hogy Spinoza úgy véli, az emberek többsége alapvetően nem az eszét, hanem a vak kivánságát követi [Spinoza 1980: 21], ezért a babonák elleni harc nem sok sikerrel kecsegtet. ${ }^{3}$ A Teológiai-politikai tanulmány előszavában szinte a nietzschei pretextusok világát idéző elhatárolódással találkozhatunk:

„Tudnék még többet hozzáfüzni, de nem akarom, hogy ez az előszó kötetté duzzadjon, fóleg mivel azt hiszem, hogy a födolgok untig ismertek a filozófusok előtt. Másoknak azonban nem ajánlom ezt a tanulmányt, mert nincs okom azt

${ }^{3} \mathrm{~A}$ sokszor pejorative citált idézet a kis halakról és a nagy halról [Spinoza 1984: 228] is korának nyelvi kontextusában a babonák elemésztő jellegére utalhatott. [Senn 2000: 55] remélni, hogy bármilyen tekintetben tetszhetnék nekik. Hiszen tudom, milyen makacsul ragaszkodik a szellem azokhoz az elöítéletekhez, amelyeket a jámborság színe alatt magáévá tett a lélek. Tudom azt is, hogy a tömegből éppúgy nem irtható ki a babona, mint a félelem. Tudom végül, hogy a tömeg állhatatossága nyakasság, hogy nem az ész kormányozza, hanem szenvedély ragadja dicséretre és gáncsra. A tömegnek tehát és mindazoknak, akiket ugyanolyan indulatok mozgatnak, mint a tömeget, nem ajánlom e könyv olvasását." [Spinoza 1984: 18]

A rávezetés, a meggyőzés eleve lehetetlen, felesleges is próbálkozni vele: inkább arra van szükség, hogy a tömegtől elkülönülő filozófus munkálkodhasson, és véleményeinek szabad kiművelésével küzdhessen a terjedő butaság ellen. A filozófus tevékenysége szegregáltsága dacára nem marad hatástalan: újabb és újabb gondolkodó lényt vezethet rá az igazságra, ugyanis a felismeréseit a tanítvány a mesteréhez hasonló bizonyossággal képes rekapitulálni [Spinoza 1984: 20].

A filozófus által elért természetes tudás isteni jellegü, mivel a világ maga is kifejezi az isteni lényeget [Takács 1994: 27]; ez rokonítja a gondolkodót a prófétával, ám adódik egy fontos különbség is. A próféta nem a teremtett dolgok rendjével foglalkozik, hanem az isteni kinyilatkoztatásra támaszkodik. Ahhoz, hogy az isteni üzeneteket érzékelni tudja, a képzelőerő fokozott aktivitására van szüksége, hiszen Krisztust kivéve, minden próféta csak szavak és képek által ismerte meg Isten kinyilatkoztatását [Spinoza 1984: 26-27]. Szemben a filozófussal, aki képes újabb filozófusokat nemzeni, a prófécia hallgatásától nem lesz senki sem próféta [Spinoza 1984: 20]. Az amúgy is gyanús, bizonytalan státuszú prófétálást [Spinoza 1984: 34] mintha asszociatív párhuzamba lehetne állítani a megalapozatlan vélemények misztifikáló erejével: a probléma az igazságérték garanciális feltételeinek hiányával van. Ezzel összefüggésbe hoz- 
ható, hogy Spinoza ugyan a (csak minimálisan korlátozott) véleményszabadság pártján áll, ám elvitatja mindenféle külön egyházi hatalom létjogosultságát [Spinoza 1984: 278], ugyanis az a babonaságra támaszkodva elnyomja a polgárokat, s így ellehetetleníti magát a szabad gondolkodást is.

A demisztifikációnak Spinozánál számos aspektusa van, ám itt most csak egy vonatkozás felidézésére van lehetőség. Nietzsche is kiemelte a teleológia tagadásának jelentőségét: a vélt szellemi rokonság egyik szimptomatikus pontja ez volt. Spinoza számára a teleologikus gondolkodás a hétköznapi instrumentalizmus mintájára képzett előítélet: mintha a természet azzal a céllal jött volna létre, hogy lehetővé tegye az emberi szükségletek kielégítését. A kritika, amely az antropomorf szemlélet univerzális érvénnyel való felruházására vonatkozott, kétség kívül szimpatikus volt Nietzschének. Spinoza kijelenti, hogy a természeti szükségszerűség ellentmond a teleológiai előítéleteknek:

„Mégis hozzáteszem, hogy ez a célról szóló tanítás teljesen feje tetejére állítja a természetet. Mert ami valójában ok, azt okozatnak tekinti, és viszont. Azután, ami természete szerint korábbi, azt későbbinek veszi." [Spinoza 1969: 49]

Nietzsche is a felcserélésnek ezt a sajátos struktúráját mutatja ki és bírálja a teleologikus gondolkodásban [Nietzsche 2004: 26]. Az egyezés azonban csupán motivikus és nem tartalmi, ugyanis egy lényeges ponton eltér az érvelése: Nietzsche a Bálványok alkonyában éppen Istent nevezi meg oknak megtett utolsó okozatként, mint absztrahált „gőzpamacsot” [Nietzsche 2004: 26]. A sorrend megbolygatása a filozófusok sajátos észhasználatának tudható be, amely búnben Spinoza is vétkes.

Korábban már szó esett róla, hogy Nietzsche az intenzív, ám rövid rajongást követően kifejezetten negatívan ítélte meg Spinoza szerepét: ebben különös hangsúlyt kapott a spinozai ész-fogalom. Az első nekibuzdulás után, mikor már alaposabban foglalkozott a filozófuselőd gondolataival, ${ }^{4}$ nem az ösztönök bölcselőjét [KGB III/1: 111] látta benne, hanem a tradicionális filozófia és észhasználat egy kivételesen virtuóz művelőjét. A korábbi kapcsolódási pontokról, affirmatív tételekről igyekezett kimutatni, hogy egészen más késztetések állnak azok hátterében Spinoza esetében, mint az övében. Például a moralitás spinozai elutasítása mögött Nietzsche egy sajátosan értett Isten-bizonyíték feltételét fedezi fel [Nietzsche 2002: 182]. A korábban inspiráló gondolatként elkönyvelt amor intellectus Dei, amely az Etikában leváltja a passzív affektusok elleni aktív affektusokkal való terápiás küzdelmet [Boros 1997: 210-227], már puszta intellektuális koholmánynak tűnik Nietzsche a szemében. Az önazonos pont bizonyossága, a szilárd alap igénye felfüggeszti a demisztifikáció szubverzív aktivitását, sőt tulajdonképpen misztifikációba torkollik. Persze eleve érthetetlennek tûnhet, hogy Nietzsche egyáltalán hogyan láthatott szubverzív gondolkodót éppen az Etika írójában. Hozzá kell azonban tenni, hogy Nietzsche rajongó értelmezésének alapja éppen a frissen megtalált, majd viszonylag hamar el is ejtett kontra-intuitív szemléletben rejlett.

\section{FILOZÓFIAI SZUBVERZIÓ VAGY POLITIKAI FELFORGATÁS}

Nietzsche értelmezői attitűdje azonban nem tűnik annyira szokatlannak, amennyiben figyelembe vesszük Spinoza munkásságának korai recepciótörténetét. A gondolkodó életútját az amszterdami zsidó közösséggel való szakítás után végigkísérte a felforgatás, hitetlenség és erkölcstelenség vádja: a gyakran idézett ko-

\footnotetext{
${ }^{4}$ A korabeli feljegyzései arra utalnak, hogy Nietzsche elsősorban (legalábbis az intenzív érdeklődés idején) másodlagos forrásokra, főleg Kuno Fischer Geschichte der neuern Philosophie címú munkájára támaszkodott [Sommer 2012; Nietzsche 2001a: 74-75].
} 
rai életrajzok ebben a kontextusban helyezik el a szerzőt. Spinoza mintha maga lenne a par excellence szubverzív gondolkodó: ennek ellensúlyozására tanítványai és baráti körének tagjai igyekeznek mentegetni őt, szinte szentként beállítani [Lucas 1980: 339]. A történetileg kétes jelentőségű exkommunikációtól [Colerus 1980: 353-359; Staller 2008: 153-154] kezdve állandóan istentelenséggel és blaszfémiával vádolták. Az álláspontját tisztázni hivatott művek sajátos kijelentései csak tovább rontották a helyzetét: például szolgál erre a Teológiai-politikai tanulmány inkriminált része, amelyben a hátát mutató Istenről értekezik [Spinoza 1984: 24].

Spinoza munkáinak nagy része olvasható akár a szubverzió vádjával szembeni védekezésképpen is. Bár a filozófiai tevékenységben már annak ókori kezdeteitôl benne rejlett a felforgatás lehetősége, a karteziánus paradigma beköszöntével az ismeretelméleti szubverzió a bölcselet - ha nem is szükségszerű - de mindenképpen szerves része lett. Míg azonban maga az episztemológiai rotáció a legtöbb ember szemében nem jelent veszélyforrást, annak egykét etikai-politikai következménye már annál nagyobb kockázatot képviselhet. Descartes az Értekezés a módszerről című irásában így védekezik az ilyen megközelítésekkel szemben:

„Ennek példájára arra a meggyőződésre jutottam, hogy valóban nem értelmes dolog, ha egy egyes ember olyképpen akarna egy államot megreformálni, hogy mindent alapostul megváltoztat, mindent felforgat benne, hogy azután újra építse; [...] Ezért semmiképpen sem helyeselhetem azoknak a zavaros és nyugtalan lelkületű embereknek eljárását, akiket sem születésük, sem vagyonuk, nem tesz hivatottakká a közügyek intézésére, s akik mégis mindig valami újításon törik a fejüket." [Descartes 2000: 27]

Láthatjuk tehát, hogy az ismeretelméleti, teoretikus szubverzió milyen jól megfér a konzervativ politika-felfogással: egyáltalán nem szükségszerü, hogy a filozófiai szubverzió eti- kai-politikai forradalomhoz vezessen.

Spinoza egyes karteziánus vonásai ellenére nem volt Descartes maradéktalan híve [Boros 1997: 25], a francia bölcselő apolitikus tanácsát pedig egyáltalán nem fogadta meg: annak ellenére, hogy több szempontból is a társadalom perifériáán élt, egyértelműen kinyilvánította véleményét a politikáról, még ha nem is kívánta teljesen racionálisan átszervezni a meglévő politikai modelleket. Mivel a politikaelmélet szubverzív gesztusaira a többségi társadalom már nem csupán közönyösen tekint, ezért az ilyen jellegű írásokban hatványozottan fontos, hogy a szerző tisztázza magát a felforgatás vádja alól. Spinoza a Teológiai-politikai tanulmány alcímét is ebben a szellemben fogalmazta meg: „Néhány értekezés annak igazolására, hogy a filozofálás szabadsága, nemcsak hogy megengedhető a jámborságnak és az állam békéjének veszélyeztetése nélkül, hanem csakis az állam békéjével és magával a jámborsággal együtt szüntethető meg" [Spinoza 1984: 7]. Miközben az alcím direkt módon a szubverziót igyekszik kiiktatni, a benne foglalt provokatív paradoxon éppen hogy maga is felforgató gesztussal él. Ez az ellentmondás az iteráció műveletével oldódik fel: a felforgatás rotációja maga már nem felforgatás.

Spinoza a mű utolsó fejezetében részletesebben is bemutatja ezt a kétszeresen szubverzív eljárást. Itt a véleményszabadság (szinte) korlátlan érvényességéből indul ki: a társadalom tagjaiként csupán arról az egyéni jogunkról mondunk le, hogy esetenként saját határozatunkból cselekedjünk, nem pedig arról, hogy a többségétől eltérő véleményünk legyen [Spinoza 1984: 293]. Azt a természeti képességet és jogot ugyanis, hogy valaki szabadon ítélkezzen, senki sem tudja átruházni másra, hiszen az elidegeníthetetlen [Spinoza 1984: 291]:

„Ennélfogva a legfőbb hatalmak jogát tiszteletben tartva, senki sem cselekedhetik ugyan határozatuk ellen, de igenis, korlátlanul 
gondolkodhatik és ítélhet s következőleg beszélhet is, feltéve, hogy egyszerüen csak beszél vagy tanít, s egyedül ésszel védi meg álláspontját [...]." [Spinoza 1984: 293]

Spinoza nem feltételezi automatikusan a cselekvés közösségével a gondolat közösségét is: ahhoz, hogy egységes államunk legyen, nem szükséges egyformán gondolkodunk. Az eltérő véleményük miatt gonosztevőként száműzött emberek pedig nem bűnt követtek el, hanem egyszerűen csak nem tudtak színlelni: ezt pedig inkább erénynek kellene tartanunk [Spinoza 1984: 298]. A divergens gondolkodás tulajdonképpen az állam üdvére van, míg a homogenizáló törekvés nyomorba dönti a társadalmat. A szubverzív elgondolás konklúzióját levonva ezt írja:

„Mindez napnál világosabban bizonyítja, hogy inkább azokat kell szakadárnak tekinteni, akik mások írásait kárhoztatják és az orcátlan tömeget az írók ellen uszítják, mintsem magukat az írókat, akik többnyire csak tudósoknak írnak s egyedül az észt hívják segítségül. Sőt valójában azok az igazi felforgatók, akik a szabad államban az ítélet szabadságát akarják megszüntetni, holott ezt nem lehet elfojtani." [Spinoza 1984: 299-300]

Spinoza a politika praktikus vetületét is elemezte: Politikai tanulmány című írásában igyekszik elkerülni a filozófusok utópikus értelmezéseit, és helyette a különböző államformák helyes megszervezését kívánja rekonstruálni [Spinoza 1980: 17-18]. Itt most nem keríthetünk sort a gondolatmenet rekapitulálására, helyette csak egy sajátos mozzanat kiemelésére van lehetőség, amely érdekes kapcsolatban áll az eddigi szubverzió-magyarázatokkal. Spinoza a különböző antik és biblia példák mellett leggyakrabban Machiavelli szövegeire hivatkozik, amely persze nem meglepő, ha arra gondolunk, hogy mindketten szerettek volna az állam működéséről morálmentesen írni. Spinoza ezen túlmenően is mintha szimpátiá- val viseltetett volna a firenzei gondolkodóval szemben: ennek akár az is lehetett az oka, hogy Machiavellit hozzá hasonlóan diabolikus alakként kezelték. A két elkötelezett republikánust egyaránt gyanúba keverte egy-két kijelentése; II. Frigyes császár úgy összegezte ezt, hogy amit Spinoza jelentett a hitnek, az volt Machiavelli az etikának - mindketten az alapok tönkretevői voltak [Lucchese 2009: 7].

A tanulmányban van egy érdekes passzus, amely mintha ezt a sorstárs-jelleget támasztaná alá. Spinoza felveti a kérdést, hogy ez a „rendkívül éles elméjű férfiú" miért részletezte annyira azoknak az eszközöknek a felsorolását, amelyek a fejedelem uralmát tartósítják. A válaszát különös perspektívából fogalmazta meg: „Ha mégis volt valami jó célja, mint ahogy ilyen bölcs férfiról feltehető, az bizonyára az volt, hogy kimutassa, milyen balgán igyekeznek sokan láb alól eltenni a zsarnokot, holott az okokat, amelyek zsarnokká teszik a fejedelmet, nem tudják megszüntetni, sőt ellenkezőleg [...] Ezenkívül talán azt akarta megmutatni, menynyire kell a szabad sokaságnak óvakodni attól, hogy feltétlenül egyetlen emberre bízza az üdvét [...]." [Spinoza 1980: 40]

A zsarnokölés példája annyira kontextusidegennek hat, hogy jó okunk van feltételezni, hogy inkább kimagyarázó mentegetéssel élt itt Spinoza, mintsem affekcióktól mentes érveléssel. Kérdés, hogy Spinoza Machiavellire irányuló figyelme milyen szerepet játszott Nietzsche értelmezésében?

\section{NiETZSCHE MACHIAVELLIÁNUS SPINOZÁJA ILLETVE SPINOZAI MACHIAVELLIJE}

Ha alaposabban megnézzük Nietzsche hátrahagyott, Spinoza gondolatait elemző feljegyzéseit, figyelmesek lehetünk valamire: amikor éppen elfogadja Spinozát, akkor a harcot, a hatalomvágyat, a virtust és a sors szükségszerüségét olvassa bele, amikor pedig elítéli, éppen ezeket 
hiányolja. Különösen kedves témája az erény (virtus) erkölcsmentes értelmezése, a hatalomgyakorlás képességéhez való közelítése, illetve a „jón fogalmának produktivitást elősegítő értelme [KSA 12: 261; Nietzsche 2001a: 74-75].

A virtus morálmentesítése különösen fontos Nietzsche számára, azonban nem ő volt az első, aki ezzel próbálkozott. Quentin Skinner kimutatta, hogy Machiavelli mint az antik auktorok kiváló ismerője műveiben különféle stilisztikai eszközökkel állandóan visszautalt olyan szerzők koncepcióira, mint Cicero vagy Seneca, de ironikus eljárásokkal éppen hogy teljesen kiforgatta, szándékosan átértelmezte azokat [Skinner 1996: 50sk]. Az igazságossággal korreláló virtus fogalmából megalkotta a virtù etikai terminusát, amely éppenséggel a lehetőségek erélyes kihasználását, aggályok nélküli kiaknázását fogalmazza meg. Érdekes, hogy ezeket a Nietzsche elgondolásaival rokonítható észrevételeket a német gondolkodó éppen Spinoza kapcsán rögzíti - talán Nietzsche nem éppen a machiavelliánus magot kereste Spinozában?

Miután Nietzsche számos helyen kritizálta a majdnem affirmálható spinozai gondolatokat, az Antikrisztus egy helyén mintha ő maga leírná, mit is várt volna el az elődtől:

„Mi jó? - Mindaz, ami az emberben növeli a hatalom érzését, a hatalom akarását, növeli magát a hatalmat. [...] Mi a boldogság? Annak érzése, hogy a hatalom növekszik, s legyőzetik az ellenállás. Nem megelégedettség, hanem több hatalom; nem egyáltalában vett béke, hanem háború; nem erény, hanem derekasság (vagyis reneszánsz-stílusú virtù, moráliáktól mentes erény)." [Nietzsche 2007: 9].

Nietzsche ebben az idézetben a kritikai pontokat módosítja affirmálható minőségekké. ${ }^{5}$ Ezek jó része mintha Machiavelli hatását mutatná; sőt a „reneszánsz-stílusú virtù” kifejezés

${ }^{5}$ Nietzsche többször Spinoza szemére veti a béke-pártiságát. [Nietzsche 2001a: 50.] hangsúlyosan Machiavellit idézi: a hatalom akarásának koncepcióját és a firenzei filozófus fogalmát nem nehéz rokonítani [Vacano 2007: 100]. Ennek ellenére Nietzsche munkáiban nem igazán találkozunk Machiavelli nevével: a „machiavellista” jelző néha ugyan elö- előfordul a kései szövegekben [KSA 11: 437; Nietzsche 2002: 328], ám nem különösebben produktív értelemben. Az a lehetőség viszont, hogy Nietzsche nem olvasta Machiavelli munkáit, elég valószínútlennek tünik, hiszen például a Machiavelli számára a virtus példájaként is szolgáló Cesare Borgia Nietzschénél is jelentőségre tesz szert [Nietzsche 2003b: 55; 2007: 111].

$\mathrm{Ha}$ alaposabban kutatunk, találhatunk is egy feljegyzést az „il principe” firenzei stílusáról [KSA 11: 454], illetve egy korai, Nietzsche iskolás éveiben (1862-ben) keletkezett levelet. Ebben a Pfortából hazaküldött lapjában tájékoztatja édesanyját („Liebe Mamma!”), hogy mennyi pénzre van szüksége: a kiadási tételek között szerepel egy „il principe” című könyv, amelyet az iskolai olasz körben olvasnának el [KGB I/1: 195]. Nietzsche tehát feltehetően nagyon korán megismerkedett Machiavelli legismertebb múvével - már persze, ha az édesanyja adott rá neki pénzt. Feltehetően igen, mivel egy kései feljegyzésében Nietzsche már egyértelmüen jelzi a hatástörténeti összefüggést: ebben a jegyzetben magához közel álló gondolkodónak titulálja A fejedelem szerzőjét [KSA 13: 625].

\section{SPINOZA DÉLUTÁNJA}

Lehetséges tehát, hogy Nietzsche nem tudatosan voltaképpen a Machiavelli-féle oltványt, az itáliai filozófus erény-rotáló hatását kereste Spinozában. Amint rájött, hogy nem azt találta, amit keresett, elfordult a filozófus alakjától. A Túl jón és rosszon című írásában a „bőgőmasina” és „méregkeverö" Spinozát [Nietzsche 2000: 29] matematikai „hókuszpókusza” miatt ítéli el, hiszen páncélt adott koncepciójára, 
leplező maskarába öltöztette, pedig, mint a következő töredékben írja, a filozófia voltaképpen akaratlan memories [Nietzsche 2000: 13]. Ezt a vonatkozást elrejteni, és a gondolatot egy „hideg isten" tetteként beállítani nem egyeztethető össze a virtussal.

Ezzel párhuzamosan még kései műveiben is olykor elismerte Spinoza kiválóságát: Nietzsche a szellemi rokonság érzetét véglegesen nem akarta vagy nem tudta kiirtani. Egyik hátrahagyott jegyzetében [KSA 12: 314] szcenírozott formában újra felidézi Spinoza szellemi nagyságát. Az aforizmát nem sokkal később, kibővített formában beledolgozta az Adalékok a morál genealógiájához című művébe:

„Egy unalmas délutánon, valami réges-régi emlék nyomán, Spinozában meghökkentő módon ötlött föl a kérdés (interpretátorai boszszúságára, akik szakadatlanul azon fáradoznak, mint például Kuno Fischer, hogy e ponton mindenáron félreértsék őt), hogy mi is maradt meg benne abból a híres-nevezetes morsus conscientiae-ből - őbenne, aki jót és gonoszt az emberi képzelet művei közé száműzött és elszántan védelmezte "szabad“ Istenének becsületét azokkal a rágalmazókkal szemben, akik azt állították, hogy Isten csak a sub rationae boni cselekszik [...] Spinoza számára a világ ismét visszatért az ártatlanság azon állapotába, amelyben a rossz lelkiismeret feltalálása előtt leledzett [...] Évezredeken át a büntetésnek alávetett bűnelkövetők tulajdon bűntetteikkel kapcsolatban pontosan úgy vélekedtek, mint Spinoza: »ltt bizony valami félresikeredett. «És nem a következőt gondolták: »Ezt azért mégsem kellett volna tennem." [Nietzsche 1996: 93-94]

Nietzsche ebben a részletben újra szellemi partnerének tekinti Spinozát, ismét a számára affirmálható módon értelmezi őt, s a különbségeket interpretátorai tévedésének tudja be. Megadta neki a gonosztevők ártatlanságát is, amelyet azelőtt oly sokszor hiányolt belőle: mintha Nietzsche még egyszer meg akarta volna idézni Spinoza árnyát, dialógusba hívni a szellemét, hogy újra eleven kísértetként emlékezhessen rá.

Felhasznált irodalom

[1.] BOROS GÁBOR [1997]: Spinoza és a filozófiai etika problémája, Atlantisz, Budapest.

[2.] Colerus, JohAnnes [1980]: Benedictus de Spinoza rövid, de igaz életrajza, Szemere Samu ford. = Spinoza: Politikai tanulmány és levelezés, Akadémiai, Budapest, 349-382.

[3.] DeleuZE, GIlles [1999]: Nietzsche és a filozófia, Moldvay Tamás ford., Gond-Alapítvány - Holnap, Budapest.

[4.] Deleuze, GIlles [2000]: Spinoza és a kifejezés problémája, Moldvay Tamás ford., Osiris - Gond Alapítvány, Budapest.

[5.] DeLEUZE, Gilles [2001]: Spinoza: Practical philosophy, translated by Robert Hurley, City Lights Books, San Francisco.

[6.] DESCARTES, RENÉ [2000]: Értekezés a módszerről, Szemere Samu ford., Múszaki, Budapest.

[7.] GerHARDT, Volker [1996]: Vom Willen zur Macht: Anthropologie und Metaphysik der Macht am exemplarischen Fall Friedrich Nietzsches (Monographien Und Texte Zur Nietzsche-Forschung), de Gruyter, New York - Berlin.

[8.] LUCAS, Maximilan [1980]: Benedictus de Spinoza úr élete és szelleme, Szemere Samu ford. = Spinoza: Politikai tanulmány és levelezés, Akadémiai, Budapest, 325-347.

[9.] LUCCHESE, FILIPPO DEL [2009]: Conflict, Power, and Multitude in Machiavelli and Spinoza, Continuum, London - New York.

[10.] NIETZSCHE, FRIEDRICH [1975-1981]: Nietzsche Briefwechsel, Kritische Gesamtausgabe herausgegeben G. Colli und M. Montinari, I. Abteilung, 1. Band - III. Abteilung, 1. Band, Walter de Gruyter, Berlin - New York. 
[11.] NIETZSCHE, FrIEDRICH [1996]: Adalékok a morál genealógiájához, Romhányi Török Gábor ford., Holnap, Budapest.

[12.] NIETZSCHE, FrIEDRICH [1999]: Sämtliche Werke. Kritische Studienausgabe herausgegeben von G. Colli und M. Montinari. I-XV., Deutscher Taschenbuch Verlag - de Gruyter, München.

[13.] NieTzSCHE, FRIEDRICH [2000]: Túl jón és rosszon, Tatár György ford., Műszaki, Budapest.

[14.] NIETZSCHE, Friedrich [2001a]: „Az új felvilágosodás”, Kurdi Imre ford., Osiris - Gond-Cura Alapítvány, Budapest.

[15.] NIETZSCHE, FRIEDRICH [2001b]: Wagner esete, Romhányi Török Gábor ford. = F. N.: Wagnerről és Schopenhauerről, Holnap, Budapest.

[16.] NIETZSCHE, FrIEDRICH [2002]: A hatalom akarása, Romhányi Török Gábor ford., Cartaphilus, Budapest.

[17.] NIETZSCHE, FRIEDRICH [2003a]: A vidám tudomány, Romhányi Török Gábor ford., Szukits, Szeged.

[18.] NIETZSCHE, FrIedRICH [2003b]: Ecce Homo, Horváth Géza ford., Göncöl, Budapest.

[19.] NIETZSCHE, FRIEDRICH [2004]: Bálványok alkonya - Nietzsche kontra Wagner, Romhányi Török Gábor ford., Holnap, Budapest.

[20.] NIETZSCHE, FrIedRICH [2007]: Antikrisztus, Csejtei Dezső ford., Attraktor, Máriabesnyő - Gödöllő.

[21.] NietzSCHE, FrIEDRICH [2008]: Emberi, nagyon is emberi, Horváth Géza ford., Osiris, Budapest.

[22.] NIETZSCHE, FrIedRICH [2012]: Emberi, nagyon is emberi, Második kötet, Horváth Géza ford., Cartaphilus, Budapest.

[23.] SENN, MARCEL [2000]: A nagy halak és a kis halak jogairól - Spinoza jogról szóló tanításának jelentőségéről, Csatár Péter ford. = Boros Gábor (szerk.): Individuum, közösség és jog Spinoza filozófiájában, Áron, Budapest, 47-71. p.

[24.] SKINNER, QUENTIN [1996]: Machiavelli, Pálosfalvi Tamás ford., Atlantisz, Budapest.

[25.] SOMmeR, ANDREAS URS [2012]: Nietzsche's Readings on Spinoza: A Contextualist Study, Particularly on the Reception of Kuno Fischer, Journal of Nietzsche Studies, Vol. 43, No. 2 (Autumn), 156-184. p.

[26.] SPINOZA, BARUCH [1969]: Etika, Szemere Samu ford., Magyar Helikon, Budapest.

[27.] SPINOZA, BARUCH [1980]: Politikai tanulmány, Szemere Samu ford. = B. S.: Politikai tanulmány és levelezés, Akadémiai, Budapest, 13-100. p.

[28.] SPINOZA, BARUCH [1984]: Teológiai-politikai tanulmány, Szemere Samu ford., Akadémiai, Budapest.

[29.] StALleR TAMÁs [2008]: Baruch vs. Benedictus: A Spinoza-jelenség, Logos, Budapest.

[30.] TAKÁcs ÁDÁM [1994]: Immanencia és etika: Tanulmány Gilles Deleuze Spinoza-interpretációjáról = Boros Gábor (szerk.): Spinoza-tanulmányok, Áron, Budapest, 23-41. p.

[31.] VACANO, Diego A. von [2007]: The Art of Power: Machiavelli, Nietzsche, and the Making of Aesthetic Political Theory, Lexington Books, Lanham.

[32.] WollenBERG, DAVID [2013]: Nietzsche, Spinoza, and Moral Affects, Journal of the History of Philosophy, Vol. 51, No. 4. (October), 617-649. p.

[33.] Yovel, YIRMIYAHU [1989]: Spinoza and Other Heretics: The Adventures of Immanence, Princeton University Press, New Jersey - Oxford.

A kutatás a TÁMOP 4.2.4.A/2-11-1-2012-0001 azonosító számú Nemzeti Kiválóság Program - Hazai hallgatói, illetve kutatói személyi támogatást biztosító rendszer kidolgozása és múködtetése országos program című kiemelt projekt keretében zajlott. A projekt az Európai Unió támogatásával, az Európai Szociális Alap társfinanszírozásával valósul meg. 